\title{
Detection of Beet Necrotic Yellow Vein Virus by Double Stranded RNA Analysis
}

\author{
Handan Çulal Kılıç ${ }^{1}$, Nejla Yardımcı ${ }^{1}$ \& Gözde Urgen ${ }^{1}$ \\ ${ }^{1}$ Department of Plant Protection, Faculty of Agriculture, Süleyman Demirel University, Turkey \\ Correspondence: Handan Çulal Kılıç, Department of Plant Protection, Faculty of Agriculture, Süleyman Demirel \\ University, Isparta, Turkey. Tel: 90-246-211-4861. E-mail: handankilic@sdu.edu.tr
}

Received: December 6, 2013 Accepted: December 23, 2013 Online Published: December 25, 2013

doi:10.5539/ijb.v6n1p95 URL: http://dx.doi.org/10.5539/ijb.v6n1p95

\begin{abstract}
Beet necrotic yellow vein virus (BNYVV), the type member of the Benyvirus genus, has a multipartite, positive-sense single-stranded RNA genome, which consists generally of four, or in some isolates five, distinct RNA species. In this study, 108 BNYVV infected soil samples were collected from Isparta province, Turkey. Sugar beet plants cv Kasandra were grown in these soil samples using bait plant techniques and root samples were then analyzed by dsRNA analysis. The RNA was purified by CF-11 cellulose chromatography and gel electrophoresis. In 108 samples tested, dsRNA profiles were observed in 53 samples. No dsRNA bands were observed in negative control used in the analysis.
\end{abstract}

Keywords: sugar beet, BNYVV, rhizomania, dsRNA analysis

\section{Introduction}

Rhizomania is caused by Beet necrotic yellow vein virus (BNYVV). Rhizomania causes serious disease of sugar beet. It was first reported in Italy in the 1950s (Canova, 1959) but now it is present in sugar beet areas all over the world (Chiba et al., 2011). BNYVV is transmitted in soil by zoospores of plasmodiophorid, Polymyxa betae (Keskin, 1964). BNYVV is member of the genus Benyvirus (Tamada, 1989). BNYVV is characterized by rod-shaped particles, $20 \mathrm{~nm}$ in diameter and four different model lengths 85, 100, 265 and $390 \mathrm{~nm}$ (Putz, 1977) containing four seperate single stranded genomic RNAs of 1467, 1774, 4612 and 6746 base pairs, respectively.

In some Asian, French and English isolates, 5th RNA, which is 1349 nucleotide long has been described (Saito et al., 1996; Koenig et al., 1997; Harju et al., 2002; Ward et al., 2007). RNA 1 and RNA 2 have "housekeeping" genes involved in replication, assembly and cell to cell movement, whereas RNA 3, RNA 4 and RNA 5 are associated with vector-mediated infection and disease development in sugar beet roots (Tamada, 2007).

The first sign of rhizomania disease in a sugar beet crop appears as light green or yellow irregularly shaped patches in the field. Individual plants show the characteristic proliferation of fibrous roots around the tap root, "the root madness symptoms" of rhizomania. In severely infected plants, the tap root and lateral roots become necrotic and die then and the vascular tissue develops a pale brown coloration (Brunt \& Richards, 1989).

BNYVV leads to serious decreases in root yield and quality of sugar. Virus reduces sugar content in the roots by $3-4 \%$ and yields of sugar beet more than 50-60\% (Henry, 1996).

In Turkey, Rhizomania was first detected in Alpulu Sugar Refinery area. Later the presence of the disease was reported in different beet growing areas of Turkey (Vardar \& Erkan, 1992; Kıymaz \& Ertunç, 1996; Ertunç et al., 1998; Kutluk-Y1lmaz \& Yanar, 2001; Kaya, 2009).

More than $90 \%$ of plant viruses have single or double stranded RNA genomes. During the replication of single-stranded RNA viruses, a complementary strand of viral RNA is synthesized. An annealed dsRNA can be isolated by phenol extraction (Zaitlin \& Hull, 1987). Morris \& Dodds (1979) developed methods for the isolation and analysis of viral dsRNAs in diseased plant tissue.

Analysis of dsRNA has been used as a means of virus detection in various crops (Rezaian \& Krake, 1987; Monette et al., 1989; Yardımcı \& Açıkgöz, 1997; Bostan \& Açıkgöz, 2000; Yardımcı \&Korkmaz, 2004; Yardımcı \& Eryiğit, 2006) including sugar beet (Hutchinson et al., 1992; Ilhan \& Ertunç, 2001; Ertunç \& Ilhan, 2002).

This study aimed to identify BNYVV on sugar beet plants by dsRNA analysis. 


\section{Materials and Methods}

\subsection{Sampling}

Soil samples were collected in August and September 2011 from soils used in sugar beet culture of Isparta Isparta province. The samples were selected considering the visual indications for the presence of rhizomania in field-grown sugar beet plants, such as yellow coloration of leaves and beard-like appearance of the roots (Figure 1). Each sample consists on a mixture of 5 sub-samples collected from different parts of the same fields.

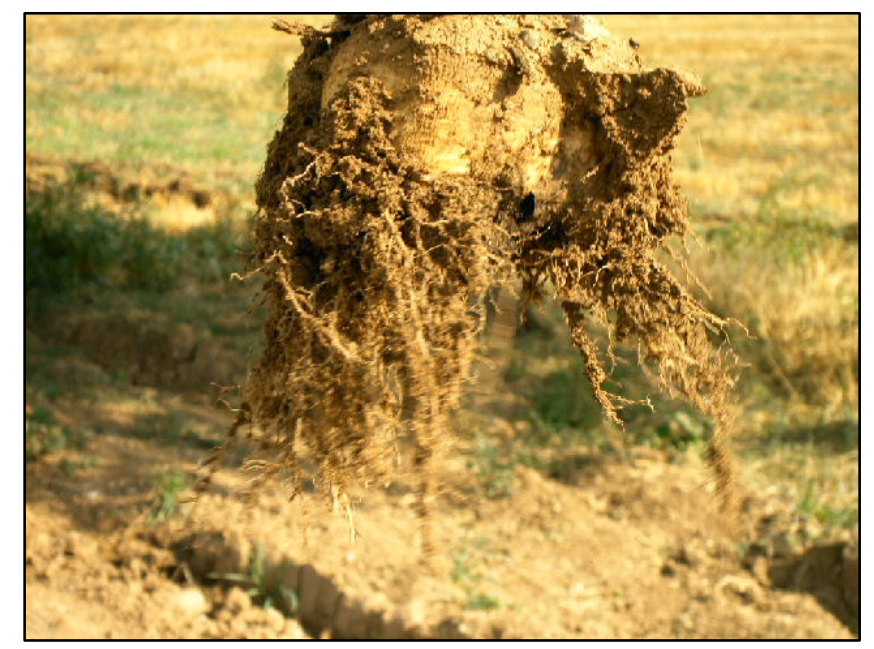

Figure 1. Typical root symptoms of Rhizomania in field-grown sugar beet plants in Gonen region, Isparta Province

\subsection{Bait Plant Technique}

The soil samples were air dried for 3-4 weeks placed in sterilized pots and 10 seeds of Beta vulgaris cv. Kasandra were sown in each pot. Sugar beet plants were grown for 9 weeks in the greenhouse at $23{ }^{\circ} \mathrm{C}$ then roots from each pot were harvested separately. Pots containing sterilized soil were used as negative control. Roots were placed into polyethylene bags labeled and stored at $-20{ }^{\circ} \mathrm{C}$ until dsRNA analysis was performed.

\section{3 dsRNA Analysis}

The method for dsRNA extraction was performed according to Morris and Dodds (1979). $20 \mathrm{~g}$ of bait plant roots was homogenized with a mortar and pestle. It was added $1 \mathrm{ml}$ of $10 \%$ SDS, $1 \mathrm{ml}$ of $2 \%$ Bentonit, $10 \mathrm{ml}$ of 1XSTE (0.1 M NaCl, $0.05 \mathrm{M}$ Tris- HCl, 1mM EDTA, pH: 6.9), $10 \mathrm{ml}$ of water-saturated phenol and $5 \mathrm{ml}$ of Chloroform: pentanol (25:1). The homogenate was mixed for $60 \mathrm{~min}$. The homogenate was centrifuged at $8000 \mathrm{~g}$ for $20 \mathrm{~min}$. The upper aqueous phase was withdrawed and placed it in a $50 \mathrm{ml}$ centrifuge tube and $2.1 \mathrm{ml}$ of $96 \%$ Ethanol were added. The samples were stored overnight at $4{ }^{\circ} \mathrm{C} .1 \mathrm{~g}$ portion of Whatman CF-11 cellulose per sample was added. Cellulose colons were prepared with $20 \mathrm{ml}$ plastic syringe. The samples were added to one colon and let it drain completely. The colon was washed with $60 \mathrm{ml}$ of 1XSTE containing ethanol (16\%). Double-stranded RNA was then eluted with STE buffer and precipitated by adding $0.5 \mathrm{ml}$ of $3 \mathrm{M}$ Sodium acetate (pH 5.5) and $20 \mathrm{ml}$ of $96 \%$ Ethanol to each sample.

The dsRNA was stored at $-20^{\circ} \mathrm{C}$ overnight. The precipitated dsRNAs were collected by centrifuged at $8000 \mathrm{~g}$ for $25 \mathrm{~min}$. The pellet was dried and resuspended in $200 \mu \mathrm{TBE}$ (Tris, Boric Acid, EDTA). The samples were mixed with $30 \mu \mathrm{l} 3 \mathrm{M}$ Sodium acetate and $0.9 \mathrm{ml}$ of $96 \%$ Ethanol then incubated at $-20{ }^{\circ} \mathrm{C}$ overnight. After centrifugation at $5000 \mathrm{~g}$ for $20 \mathrm{~min}$. The pellet was resuspended in sterile distilled water and used in electrophoresis.

Double- stranded RNA was analysed by electrophoresis in agarose gels. The gels were electrophoresed at $100 \mathrm{~V}$ for 1 hour, stained with ethidium bromide and then visualized and photographed by Doc-It gel imaging and documentation system (UVP, England).

\section{Results and Discussion}

Typical rhizomania symptoms on leaves and roots were observed on plants growing under the greenhouse 
conditions after 9 months (Figure 2). Typical symptoms of BNYVV which are beard-like apperance of the roots, light green coloration of leaves.

dsRNA profiles typical of BNYVV were observed in 53 of 108 samples tested. However, healthy sugar beet did not show any dsRNA bands onto agarose gel. In 28 samples were observed RNA $1+2+3+4$, in 9 samples were observed RNA 3, in 7 samples were observed RNA 1+2+3, in 9 samples were observed RNA 1+3 (Figures 3-4). In this research, RNA 5 has not been identified in the analyzed samples. Profiles of dsRNA obtained in this study are shown in Table 1.

The dsRNA profile detected in this study was same as previously reported BNYVV dsRNA profiles (Hutchinson et al., 1992; Ilhan \& Ertunç, 2001; Ertunç \& Ilhan, 2002). Non-specific bands were observed in agarose gel. The main reason is thought to be the lack of enzymatic treatment.

Variable dsRNA profiles were observed in BNYVV isolates. These alterations in the deletion mutations of smaller RNAs were associated with changes in symptoms expression of BNYVV, molecular differences between the strain of BNYVV or low virus concentration in the isolates (Henry et al., 1986; Koenig et al., 1986). The yield low amount of dsRNA in infected plants is related specifically to the time of infection and incubation temperature (Valverde et al., 1990).

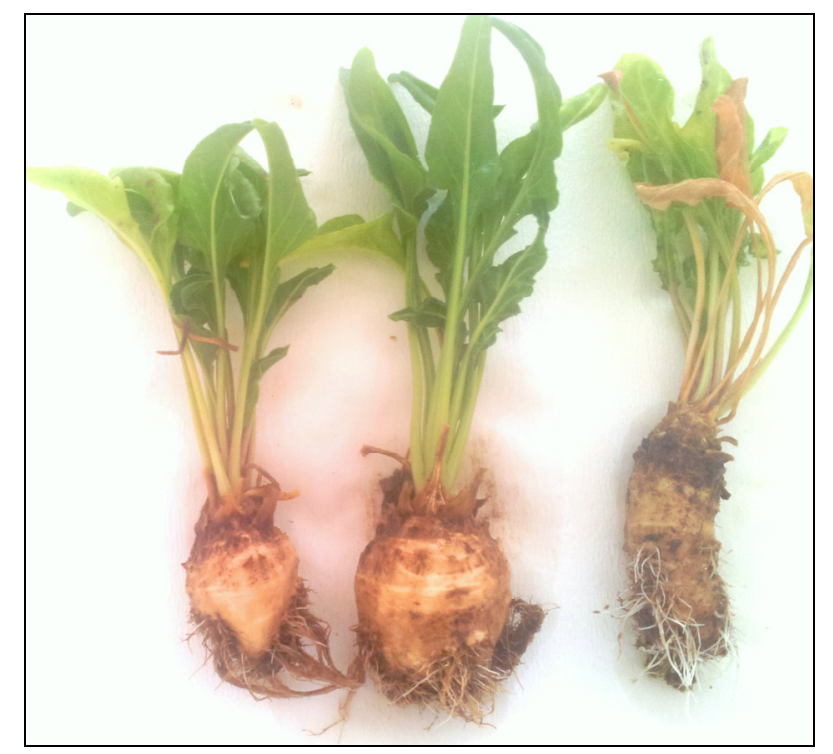

Figure 2. Beard like appaerance of bait plant roots

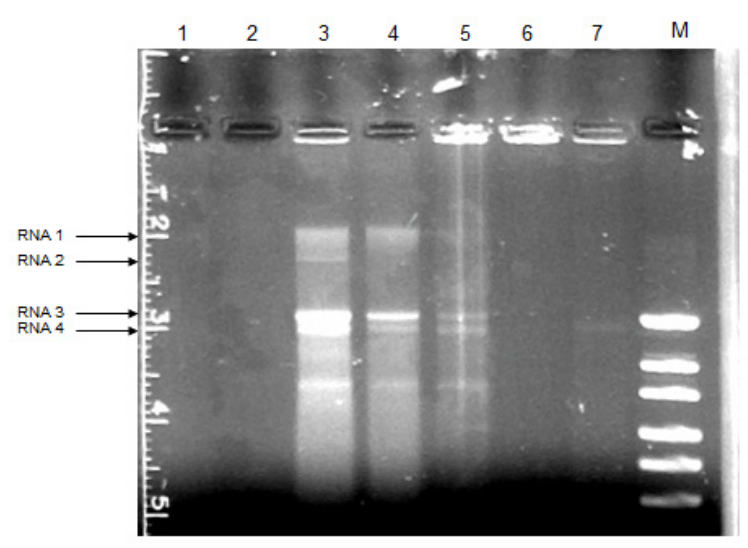

Figure 3. Agarose gel electrophoresis of dsRNA from BNYVV- Infected roots (M: Marker (100 bp-1.5 kb DNA Ladder, Biobasic); 1: Atabey-3 isolate; 2: Gonen-44 isolate; 3: Islamkoy-40 isolate; 4: Yalvac-11 isolate; 5:

Keciborlu-17 isolate; 6: Kuleonu-60 isolate; 7: Negative control 


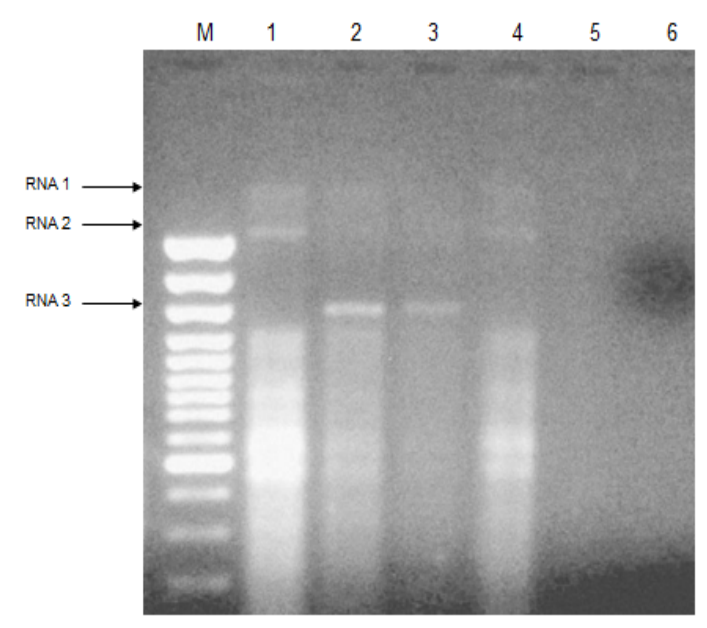

Figure 4. Agarose gel electrophoresis of dsRNA from BNYVV- Infected roots (M: Marker (100 bp DNA Ladder, Biobasic)); 1: Gonen-33 isolate; 2: Kuleonu-14 isolate; 3: Keciborlu-7 isolate; 4: Yalvac-22 isolate; 5: Senirkent 20 isolate; 6: Negative control

dsRNA analysis is simple, quick, efficient and relatively inexpensive. The purified dsRNA can be used as template for cDNA synthesis and subsequent PCR, molecular cloning, prob preparation and a reagent for mechanical inoculations (Valverde et al., 1990). dsRNA analysis is more sensitive when compared to serological tests (Ertunç \& Ilhan, 2002). A disadvantage is that this procedure can generally not be used to process a large number of samples at a time. Also, since dsRNA is related to replication of the virus the titre of the dsRNA molecule may increase or decrease in the plant at certain times of the year, thereby influencing detection.

\section{Conclusions}

We can say that practicality of using analysis of dsRNA as an alternative or complementary method for diagnosis of BNYVV. At the very least it provides a jumping-off place in the diagnostic process before proceeding to more specific techniques.

Table 1. dsRNA Profile of BNYVV on samples in different districts of Isparta Province

\begin{tabular}{ll}
\hline Samples No & dsRNA Profile \\
\hline Atabey-5 & RNA 1+2+3+4 \\
Atabey-24 & RNA 1+2+3+4 \\
Atabey-25 & RNA 1+2+3+4 \\
Atabey-78 & RNA 1+2+3+4 \\
Islamkoy-1 & RNA 1+2+3+4 \\
Islamkoy-21 & RNA 1+2+3+4 \\
Islamkoy-40 & RNA 1+2+3+4 \\
Islamkoy-48 & RNA 1+2+3+4 \\
Yalvac-2 & RNA 1+2+3+4 \\
Yalvac-11 & RNA 1+2+3+4 \\
Yalvac-41 & RNA 1+2+3+4 \\
Yalvac-23 & RNA 1+2+3+4 \\
Keciborlu-8 & RNA 1+2+3+4 \\
Keciborlu-22 & RNA 1+2+3+4 \\
\hline
\end{tabular}




\begin{tabular}{|c|c|}
\hline Keciborlu-20 & RNA $1+2+3+4$ \\
\hline Keciborlu-17 & RNA $1+2+3+4$ \\
\hline Senirkent-5 & RNA $1+2+3+4$ \\
\hline Kuleonu-66 & RNA $1+2+3+4$ \\
\hline Kuleonu-23 & RNA $1+2+3+4$ \\
\hline Kuleonu-88 & RNA $1+2+3+4$ \\
\hline Kuleonu-29 & RNA $1+2+3+4$ \\
\hline Kuleonu-67 & RNA $1+2+3+4$ \\
\hline Sarkikaraagac-77 & RNA $1+2+3+4$ \\
\hline Sarkikaraagac -1 & RNA $1+2+3+4$ \\
\hline Sarkikaraagac -95 & RNA $1+2+3+4$ \\
\hline Sarkikaraağac-15 & RNA $1+2+3+4$ \\
\hline Sarkikaraağac-58 & RNA $1+2+3+4$ \\
\hline Gonen-3 & RNA $1+2+3+4$ \\
\hline Gonen-33 & RNA $1+2+3$ \\
\hline Gonen-70 & RNA $1+2+3$ \\
\hline Gonen-2 & RNA $1+2+3$ \\
\hline Gonen-56 & RNA $1+2+3$ \\
\hline Gonen-68 & RNA $1+2+3$ \\
\hline Gonen-23 & RNA $1+2+3$ \\
\hline Gonen-99 & RNA $1+2+3$ \\
\hline Islamkoy-43 & RNA1+3 \\
\hline Islamkoy-9 & RNA1+3 \\
\hline Kuleonu-77 & RNA1+3 \\
\hline Kuleonu-78 & RNA1+3 \\
\hline Kuleonu-86 & RNA1+3 \\
\hline Kuleonu-95 & RNA1+3 \\
\hline Atabey-33 & RNA1+3 \\
\hline Atabey-11 & RNA1+3 \\
\hline Atabey-10 & RNA1+3 \\
\hline Keciborlu-7 & RNA 3 \\
\hline Keciborlu-12 & RNA 3 \\
\hline Islamkoy-12 & RNA 3 \\
\hline Islamkoy-61 & RNA 3 \\
\hline Islamkoy-10 & RNA 3 \\
\hline Islamkoy-88 & RNA 3 \\
\hline Kuleonu-14 & RNA 3 \\
\hline Gonen-28 & RNA 3 \\
\hline Gonen-81 & RNA 3 \\
\hline
\end{tabular}




\section{References}

Bostan, H., \& Açıkgöz, S. (2000). Determination of PVX and PVS symptoms on some test plants and identification of these viruses using dsRNA analysis. The Journal of Turkish Phytopathology, 29(1), 41-49.

Brunt, A. A., \& Richards, K. E. (1989). Biology and molecular biology of furoviruses. Advances in Virus Research, 36, 1-32.

Canova, A. (1959). On the pathology of sugar beet. Inf Fitopatology, 9, 390-396.

Chiba, S., Kondo, H., Miyanishi, M., Andika, I. B., Han, C., \& Tamada, T. (2011). The evolutionary history of Beet necrotic yellow vein virus deduced from genetic variation, Geographical origin and spread, and the breaking of host resistance. Molecular Plant- Microbe Interaction, 24(2), 207-218. http://dx.doi.org/10.1094/MPMI-10-10-0241

Ertunç, F., Erzurum, K., Karakaya, A., Ilhan, D., \& Maden, S. (1998). Incidence of Rhizomania disease on sugar beet in Çorum, Kastamonu and Turhal Sugar Refinery Regions. The Journal of Turkish Phytopathology, 27(1), 39-46.

Ertunç, F., \& Ilhan, D. (2002). dsRNA analysis of Turkish Beet Necrotic Yellow Vein Virus (BNYVV) isolates. The Journal of Turkish Phytopathology, 31(3), 173-183.

Harju, V. A., Mumford, R. A., Blockley, A., Boonham, N., Clovert, G. R. G., Weekes, R., \& Henry, C. M. (2002). Occurence in the United Kingdom of Beet Necrotic Yellow Vein Virus isolates which contain RNA-5. Plant Pathology, 51, 811. http://dx.doi.org/10.1046/j.1365-3059.2002.00781.x

Henry, C. M., Jones, R. A. C., \& Coutts, R. H. A. (1986). Occurrence of a soil-borne virus of sugarbeet in England. Plant Pathology, 38, 585-591.

Henry, C. (1996). Rhizomania-its effect on sugar beet yield in the UK. British Sugar Beet Review, 64, 224-26.

Hutchinson, P. J., Henry, C. M., \& Coutts, R. H. A. (1992). A comparison, using dsRNA analysis, between beet soil-borne virus and some other tubular viruses isolated from sugar beet. Journal of General Virology, 73, 1317-1320. http://dx.doi.org/10.1099/0022-1317-73-5-1317.

Ilhan, D., \& Ertunç, F. (2001). Investigation of some Furoviruses by dsRNA analysis method. The Journal of Turkish Phytopathology, 30(1), 27-34.

Kaya, R. (2009). Distribution of Rhizomania disease in sugar beet growing areas of Turkey. Journal of Agricultural Science, 15(4), 332-340.

Keskin, B. (1964). Polymyxa betae n.sp., ein Parasit in den Wurzeln von Beta vulgaris Tournefort, besonders während der Jugendent wicklung der Zuckerrübe. Archivi für Mikrobiologie, 49, 348-374.

Kiymaz, B., \& Ertunç, F. (1996). Research on the detection of virus diseases in sugar beet in Ankara. The Journal of Turkish Phytopathology, 25(1-2), 55-63.

Koenig, R., Haeberle, A. M., \& Commandeur, U. (1997). Detection and characterization of a distinct type of Beet Necrotic Yellow Vein Virus RNA 5 in a sugar beet growing area in Europe. Archives of Virology, 142, 1499-1504.

Koenig, R., Burgermeister, W., Weich, Sebald, H. W., \& Kothe, C. (1986). Uniform RNA patterns of Beet necrotic yellow vein virus in sugarbeet roots, but not in leaves from several plant species. Journal of General Virology, 67, 2043-2046.

Kutluk-Y1lmaz, N. D., \& Yanar, Y. (2001). Study on the distribution of Beet necrotic yellow vein virus (BNYVV) in sugar beet growing area of Tokat -Turkey. The Journal of Turkish Phytopathology, 30(1), 21-25.

Monette, P. L., James, D., \& Godkin, S. E. (1989). Double-stranded RNA from rupestris stem pitting affected grapevine. Vitis, 28, 137-144.

Morris, T. J., \& Dodds, J. A. (1979). Isolation and analysis of double-stranded RNA from virus-infected plant and fungal tissue. Phytopathology, 69, 854-858.

Putz, C. (1977). Composition and structure of Beet necrotic yellow vein virus. Journal of General Virology, 35, 397-401.

Rezaian, M. A., \& Krake, L. R. (1987). Nucleic acid extraction and virus detection in grapevine. Journal of Virological Methods, 17, 277-285.

Saito, M., Kiguchi, T., Kusume, T., \& Tamada, T. (1996). Complete nucleotide sequence of the Japanese isolate 
S of Beet necrotic yellow vein virus RNA and comparison with European isolates. Archives of Virology, 141, 2163-2175.

Tamada, T. (1989). Production and pathogenicity of isolates of Beet necrotic yellow vein virus with different numbers of RNA components. Journal of General Virology, 70, 3399-3409.

Tamada, T. (2007). Susceptibility and resistance of Beta vulgaris subsp.maritima to foliar rub-inoculation with Beet necrotic yellow vein virus. Journal of General Plant Pathology, 73, 76-80.

Vardar, B., \& Erkan, S. (1992). The first studies on detection of Beet necrotic yellow vein benyvirus in sugar beet in Turkey. The Journal of Turkish Phytopathology, 21(2-3), 74-76.

Valverde, R. A., Nameth, S. T., \& Jordan, R. L. (1990). Analysis of double stranded RNA for plant virus diagnosis. Plant Disease, 74(3), 255-258.

Ward, L, Koenig, R., Budge, G., Garrido, C., Mcgrath, C., Stubbley, H., \& Boonham, N. (2007). Occurrence of two different types of RNA-5-containing Beet necrotic yellow vein virus in the UK. Archives of Virology, 152, 59-73. http://dx.doi.org/10.1007/s00705-006-0832-x

Yardımcı, N., \& Açıkgöz, S. (1997). Studies of Alfalfa mosaic virus of alfalfa growing areas in Erzurum. The Journal of Turkish Phytopathology, 26(1), 23-30.

Yardımc1, N., \& Korkmaz, S. (2004). Studies on spread and identification of Zucchini yellow mosaic virus disease in the North-West Mediterranean Region of Turkey by biological indexing and double-stranded RNA analysis. Plant Pathology Journal, 3(1), 1-4.

Yardımcı, N., \& Eryiğit, H. (2006). Identification of Cucumber Mosaic Virus in tomato (Lycopersicon esculentum) growing areas in the North-West Mediterranean Region of Turkey. New Zealand Journal of Crop and Horticulture Science, 34, 173-175. http://dx.doi.org/10.1080/01140671.2006.9514403

Zaitlin, M., \& Hull, R. (1987). Plant virus-host interactions. Annual Review of Plant Physiology, 38, 291-315. http://dx.doi.org/10.1146/annurev.pp.38.060187.001451

\section{Copyrights}

Copyright for this article is retained by the author(s), with first publication rights granted to the journal.

This is an open-access article distributed under the terms and conditions of the Creative Commons Attribution license (http://creativecommons.org/licenses/by/3.0/). 